\title{
The Effectiveness of Practices and Process of Students' Placement into Different Academic Program: The Case of Madda Walabu University
}

\author{
Baru Aboma Totoba \\ Madda Walabu University, Department of Educational Foundations and Management, \\ College of Education and Behavioral Studies, P.O.BOX: 247, Bale -Robe, Ethiopia
}

\begin{abstract}
This study sought to explore the effectiveness of practice of students' placement into different departments at MWU. To achieve this objective three research questions were laid down. They were: (1) What are the criteria adopted for students 'departmental placement at MWU? (2) To what extent the criteria and practice for departmental placement, influence students 'choices of different study programs? (3) What could be possible to solve those problem? A total of 233 students of two batches in there, first and third year studies in 2012/13 were included in this study using stratified random sampling. In addition, 17 officials (university managers) were included using the availability sampling while 16(two from each selected department) instructors were selected using quota sampling technique. Questionnaire, Interview and Documents analysis were employed to collect data. Both quantitative and quantitative methods of data analysis were used as data collection instruments. The finding revealed that, the practice of student departmental placement was anticipated to be governed by five criteria adopted at MWU. The finding also revealed that there was a gap between the intended and actual practice of students' departmental placement. As a result of this 55.4\% students were assigned into their department without their' choices. Therefore, the researcher recommended the concerned body at MWU, to give due consideration to students; interests, aptitudes and preferences during selection and placement of students into various departments at this university
\end{abstract}

Keywords: Effectiveness; Students placement; the practices

DOI: $10.7176 / \mathrm{JEP} / 11-4-04$

Publication date: February $29^{\text {th }} 2020$

\section{Introduction}

The organization of universities in departments divided along disciplinary lines is a means of shaping the supply (knowledge) according to market demands and according to internal organizational requirements and choices. Because of significant shifts in terms of funding and rising costs of research over the last 20 years, universities have become increasingly subjected to market forces. This usually means that universities are increasingly encouraged to adopt better 'business practices' that can make them more competitive in the education and research market. As a result, universities have to question their current forms of management, organization and practices.

Ethiopia has shown a palpable progress in rippling higher education institutions across the country. Several universities have mushroomed nationwide. Those universities have been catering to the education demand of citizens. However, there are chasms in creating employment opportunities for graduates. Plenty of factors are ascribable to the problem. Improper department placement of students is among the setbacks. As a result, many Ethiopian university graduates have been facing unemployment.

Therefore, to develop effective recruitment strategies, university managers need to have a clear understanding of how and why the students choose a department in higher education institution. They should consider many factors in order to be selected by a student. Even though understanding the university choice process is not easy, determining the factors that influence the process can be seen as a necessary activity for university managers. Through the analysis of this process, higher education institutions can develop a comprehensive understanding of how and why the students select their academic program in higher education institution. Understanding of choice process is very important for improving their student recruitment strategies. This article examines the process of students' placement into different academic program in Madda Walabu university in detail.

\section{Statement of the Problem}

The problem of placing students to universities and to departments has always taken the attention of freshman students. There is little academic consideration while placing students to academic program within the universities. Fechner (2009) stated that giving opportunity for students to join field of study by their choices will encourage students' interests in general. An increase of interest, in turn, mediates an improved learning outcome (Adodo and Gbore, 2011). Therefore, it could be understood that students' positive attitude toward a particular 
subject might play decisive role by initiating the potentials inherent in that subject.

But in current Ethiopian University, a little attention is given to academic interests and aptitudes of students by faculty member during selection and placement of students into different program of studies. In most universities in Ethiopia specifically those newly established universities, the intake capacity of educational disciplines and the numbers of those who want to join them were not proportionate. Some disciplines were widely selected by students, while others were not selected at all. when the researcher was teaching at Madda Walabu University, he participated in students' selection and placement into different study program. During then, he knew a study program which had a vacancy to admit only 50 students, though the students who wanted to join the department were 100 . Consequently, the remaining 50 did not get admitted in to the study program of their choices. Thus, instead of closing the no-selective study program, most students were assigned to the study program they were not interested to study. However, Dessalegn (1996), has suggested that, it is appropriate to bring those fields of study having less students' choices and local market demand to terminations (phase- out) than forcing students to learn in non-selective study program without their interests.

The study about students' the effectiveness of the process and practices of department placement and the rules that govern student' departmental placement in Ethiopian universities in general and at Madda Walabu University is limited. In addition, different policy makers and policy documents provide different rules to govern students' departmental placement practices but they are still less cognizant about the actual placement practice carried out at university level. Due to this, significant numbers of students in most current Ethiopian universities were joining their study program without their first choices (by assignment).

When students were assigned to the study program they were not interested to study, unprepared students assigned in a study program difficult to them while the others assigned into one which do not fit their knowledge and feel compelled to lose their ability. Due to placement into a study program without students first choice most students' faces learning difficulties in their studies. The researcher reminds students of MWU who dropped out during their first-year education and others who repeated the courses. Therefore, according to this researcher, this was disadvantage and deprivation to an individual who has the quest and zeal to pursue his/ her educational dreams. Thus, the study about students' departmental placement process and practices at Madda Walabu University is of significance. The concern of this study is therefore to assess the effectiveness of practices and process involved in of students' placement into different study program at Madda Walabu University by answering the following questions. [1] How placement of students into different academic study carried out at MWU [2] How far students 'interests to join departments by their interest maintained at MWU [3]What are the possible solutions to maintain student's choice. The main purpose of this study was to assess the effectiveness of practices and process of students 'placement into different at the Madda Walabu University, to forward recommendations for the improvements of the problems that the study brought into light.

\section{Research Question}

The study was guided by the following sub-research questions:

(1) Know how placement of students into different academic study carried out at MWU

(2) Know how far students 'interests to join departments by their interest maintained at MWU

(3)Identify the possible solutions to maintain student's choice

\section{Methods}

In this study descriptive Case Study method was employed to describe the existing conditions and practices of students' placement into different departments at Madda Walabu University. For this study, both qualitative and quantitative research approaches were used to complement the limitation of one over the other. Madda Walabu university was purposely selected as study area since, the researcher has a very close contact as a teaching staff. Through his stay in the university the researcher has informally detected problems related to department placement practice among students in the campus and he thought it is significant to deal with at this university. This study was conducted since 2013 at Madda Walabu University and it included four schools (Faculties) of the university using systematic sampling technique. The Four School were; School of social science, language Studies, Engineering Technology and Mathematical science. Therefore, four (44.4\%) of the nine schools(faculties) running within Madda Walabu University were employed for this study. In those Schools, the study aimed to look at students' placement practices and process. About 13 departments, 8 (61\%) of them, were included in this study using stratified sampling as appropriate method for the purpose of this study. The sample departments were, Computer Science and Information technology from school of Engineering-Technology, mathematics and statistics from School of mathematical sciences, Amharic and English departments from Schools of language studies and History and Geography from School of Social Science.

Among the students MWU in 2013 first year and their third year were selected using purposive samplings from the very purpose that university students face learning difficulties in their first year of studies and students in third year of their studies have better experience of their respective department than students of the other 
batches. In this regard, this study included 233 (15 from each Departments using stratified random sampling technique) sample size of this study. Thus, a total of $115(29.7 \%)$ students in their first-year studies in the year 2012/13, comprising 58 males and 57 females and 120(37.8\%) students in their third-year studies in the year 2012/13 containing 81 males and 35 females were included in the study. In addition, 17 university officials (University department heads, School directors, Academic Vice President etc) and 16 instructors, a total of 266 respondents were used as data sources for the study. I addition policy documents and Guidelines related to students' department placement as well as individual students' GPA were used as sources of data for this study. The researcher decided to include only two instructors from each department and thus, Quota sampling was used to select 16 instructors ( 2 from each selected departments) while availability sampling was employed to select officials fulfilling questionnaires. The following table 1 indicates students' population, samples students' and sample batches, as well as sampling technique employed for this study.

Table1. Student Population, Sample and Sampling technique used in the study

\begin{tabular}{|c|c|c|c|c|c|c|c|c|}
\hline \multirow[t]{2}{*}{ No } & \multirow[t]{2}{*}{ Schools } & \multicolumn{2}{|l|}{$\begin{array}{l}\text { Sample } \\
\text { Departments }\end{array}$} & \multirow{2}{*}{$\begin{array}{l}\text { sample } \\
\text { batches } \\
3 \mathrm{rdYr}\end{array}$} & \multicolumn{2}{|c|}{$\begin{array}{r}\text { T/PopulationSample } \\
\text { students }\end{array}$} & \multicolumn{2}{|r|}{$\begin{array}{l}\text { Sampling } \\
\text { Technique } \\
\text { used }\end{array}$} \\
\hline & & & $1^{\text {st }} Y r$ & & $\mathrm{~T}$ & $1^{\text {st }} \mathrm{Yr}$ & $3 \mathrm{rdY}$ & rpurposive \\
\hline \multirow[t]{3}{*}{1} & Engineering & Inf. system & 59 & 30 & 89 & 15 & 15 & SRS \\
\hline & Technology & Computer science & 134 & 77 & 211 & 15 & 15 & SRS \\
\hline & & Math's & 58 & 49 & 107 & 15 & 15 & SS \\
\hline \multirow[t]{2}{*}{2} & Mathematical & Statistics & 62 & 51 & 103 & 15 & 15 & SRS \\
\hline & science & Amharic & 10 & 23 & 33 & 10 & 15 & AS/SRS \\
\hline \multirow[t]{2}{*}{3} & Language Studies & English & 21 & 30 & 51 & 15 & 15 & SRS \\
\hline & & History & 20 & 30 & 50 & 15 & 15 & SRS \\
\hline \multirow[t]{2}{*}{4} & Social Science & Geography & 23 & 27 & 50 & 15 & 15 & SRS \\
\hline & & Total & 387 & 317 & 704 & 115 & 120 & \\
\hline
\end{tabular}

Note $A S=$ availability sampling, SRS=Stratified random sampling, $1^{\text {st }} \mathrm{Yr}=$ First Year, $3^{\text {rd }} y r$ Year.

The major data collection instruments used in this study was questionnaire and interview. Questionnaire was used to gather both qualitative and quantitative data. Thus, close ended questions with very limited number of open-ended items was employed for gathering information from all groups of respondents as they were relatively large in number. Thus, 268 set questionnaires containing 121 items made up of 27 open-ended and 94 close-ended items, a total of 268 set of questionnaires distributed and 266 were returned after educes responses. The data on academic performance was collected through self-reported grade point average (GPA) which was earned by the participants at the end of the first semester of the 2012- 2013 academic year.

In addition, documents were employed just to complement the evidences. It was believed that utilization of such validated and multiple data collection methods as well as data sources would enable to verify the authenticity of the data that was generated.

In this study, both qualitative and quantitative data analysis methods were employed. The data collected through questionnaire were analyzed using the Statistical Package for Social Sciences (SPSS; version 16) computer software. The quantitative data were condensed into descriptive statistics such as percentages, correlation and mean. The qualitative data obtained through open-ended questionnaire, interview and documents were transcribed, and interpreted thematically. The thematic approach was followed to display the analyses and findings from both quantitative and qualitative data. Analysis of qualitative data collected through interview were displayed first and then corroborated by qualitative data analysis in the form of texts and quote.

\section{Findings}

5.1. Background Characteristics of Respondents.

All respondents, students and officials of the selected faculties and departments were asked to indicate their background information in the questionnaire. Accordingly, students were requested to fill in their faculties, departments' sex, age, academic year of the study and their stream in preparatory school whereas officials were asked to indicate in the questionnaire their background information like their sex, educational qualification, academic rank, position and year of services in the University and these were summarized as follows. 
Table 4A. Background information of student respondents

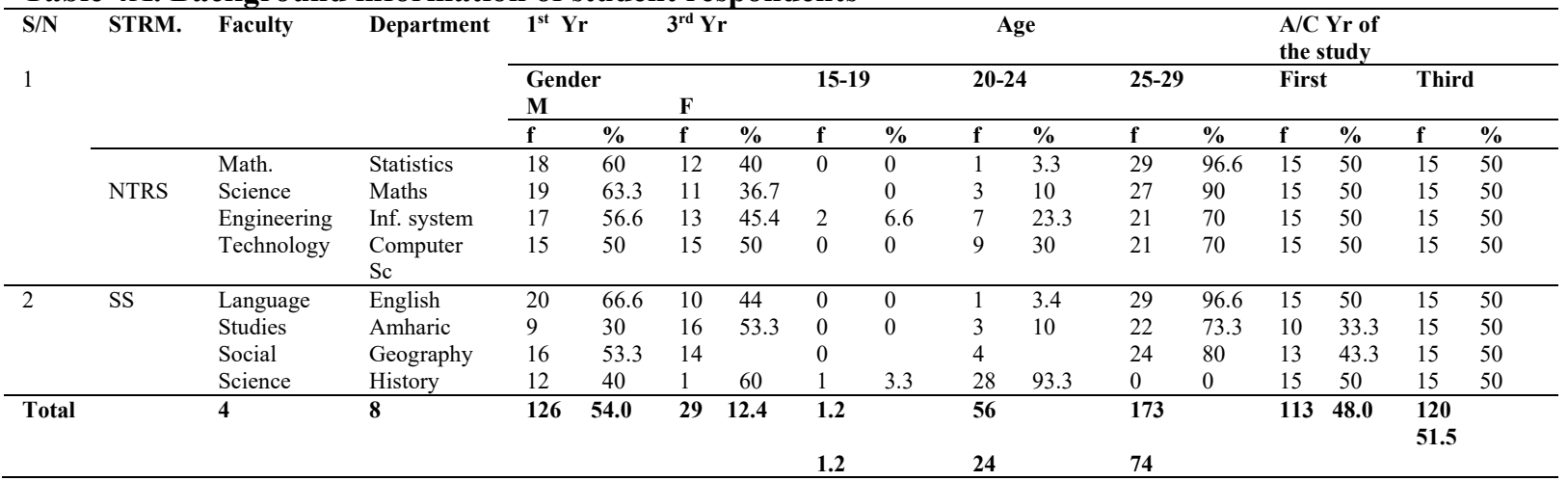

Note: A/cyr=Academic Year, F=Female, $M=$ Male, prep=Preparatory

Students' placement is carried out centrally by MoE while students placed into different department within university by university administrators. Accordingly, table above indicated that, $120(51.5 \%)$ of the students who were learning natural science stream at university and $113(48.5 \%)$ of students who were learning in social science stream at the university were placed to same stream at university by MoE. This reflects that there is no placing student out of prior experiences at central (ministry) level. As far as sex of the students' respondent concerned, table above indicated that the number, $126(54.0 \%)$ of male respondents exceed that of female respondents $107(46 \%)$ showing that male participation seems to be slightly high in relation to females. Majority of the respondents $173(74.2 \%)$ were in their age range of 24-29 indicating that they were in reasonable age range to make decision regarding their academic study choices when age of the respondent is concerned.

Table 4B. Background Information of Official Respondents

\begin{tabular}{|c|c|c|c|c|c|c|c|c|c|c|c|c|c|c|c|c|c|}
\hline \multirow[t]{2}{*}{ Items } & \multirow[t]{2}{*}{ AVP } & \multirow[b]{2}{*}{ f } & \multirow[b]{2}{*}{$\%$} & \multicolumn{2}{|c|}{ F/deans } & \multicolumn{2}{|c|}{ D/heads } & \multicolumn{2}{|c|}{ ERQD } & \multicolumn{2}{|c|}{ RGRR.D } & \multicolumn{2}{|c|}{ TLE.D } & \multicolumn{2}{|c|}{ St SD } & \multicolumn{2}{|c|}{ Total } \\
\hline & & & & f & $\%$ & f & $\%$ & f & $\%$ & f & $\%$ & f & $\%$ & f & $\%$ & f & $\%$ \\
\hline Sex & M & 1 & 5.8 & 4 & 23.5 & 8 & 47.0 & 1 & 5.8 & 1 & 5.8 & 1 & 5.8 & 1 & 5.8 & 17 & 100 \\
\hline Qualification & $\mathrm{BA} / \mathrm{ED} \backslash \mathrm{BSc}$. & - & & 1 & 5.8 & 2 & 11.7 & - & - & - & - & - & - & - & - & 3 & 17.6 \\
\hline & MA/MSc. & 1 & 5.8 & 3 & 17.6 & 6 & 35.2 & 1 & 5.8 & 1 & 5.8 & 1 & 5.8 & 1 & 58 & 14 & 82.3 \\
\hline Academic rank & Asst.prof & 1 & 5.8 & - & - & - & - & - & - & - & & - & - & - & - & 1 & 5.8 \\
\hline & GAII & 3 & 17.6 & 6 & 35.3 & 1 & 5.8 & 1 & 5.8 & 1 & 5.8 & 1 & 5.8 & 14 & 82.4 & 3 & 17.6 \\
\hline & Asst.Lec & - & - & 1 & 5.8 & 2 & 11.7 & - & - & - & - & - & - & - & - & 3 & 17.6 \\
\hline Yr. & $1-5$ & - & & 4 & 23.5 & 6 & 35.2 & 1 & 5.8 & 1 & 5.8 & 1 & 5.8 & - & - & 7 & 41.1 \\
\hline Experiences & $6-10$ & 1 & 5.8 & - & - & - & - & - & - & - & - & - & - & 1 & 5.8 & 2 & 11.7 \\
\hline & $10-15$ & - & - & 1 & 5.8 & - & - & - & - & - & - & - & - & - & - & 1 & 5.8 \\
\hline
\end{tabular}

Note: $\mathrm{A} / \mathrm{VP}=$ Academic Vice President Assistant Lec .=Assistant Lecturer, Asst. prof. $=$ Assistant Professor, $B A / E D / B S c=$ Bachelor of Art, Education or =Bachelor of Science, D/head=Department heads, ERQAD=Education Relevance and Quality Assurance Dean, F/dean=Faculty dean, GAI=Graduate Assistant I,GAII=Graduate Assistant II, $f=$ Frequency Inf. Sys=Information System,TLED $=$ Teaching-Learning Enhancement Dean, $M A / M S c=$ Masters of Art or Masters of Science Male, SD=Students Service Dean, $Y r .=y e a r$ Un $=$ University

As indicated in the table 4B above gender wise, all the five-leadership position included was dominated by male officials. This reflected that, there is gender disparity in leadership positions at the targeted University. As far as educational qualification of the officials concerned, 14(82.4\%) of them have second degree while $3(17.6 \%)$ respondents were at their bachelor degree level. Only $1(5.8 \%)$ of them was at the rank of assistant professor, $13(88.2 \%)$ of them were at the rank of lecturer while 3(17.6) of them were at the rank of Graduate assistant when academic rank of the officials concerned. Concerning official's year of experience in university, 7(41.1\%) of them has work experience in range of $1-5$ year, $2(11.7 \%)$ of them in range of $6-10$ year and only $1(5.8 \%)$ was in range of 10-15 year of work experience in university. This reflects that officials of the university understudy were as young as the university itself in their work experience in university.

\subsection{The criteria adopted for students 'departmental placement at Madda Walabu University?}

The effectiveness of the criteria guiding students' selection and placement to different academic study according to Dill (1995) is measured by the emphasis it gives to interest and ability of incoming students in relation to academic quality. This implies not only assessing students for admission on critical measures, but also systematically validating the preparation of the student body and effectiveness of selection practices and criteria while implementing selection procedures based on the essential criteria of academic quality. The first question of this study concerned with identifying the practice adopted to select and place students to different departments at Madda Walabu University. Qualitative and quantitative data regarding placement criteria and practice was obtained from 233 students of two cohorts in their1st and 3rd studies in 2012/13 academic year, 17 officials and 16 instructors of Madda Walabu University through questionnaire, interview and document 
Table 2. The Participants' response about the Process and practice adopted for students' departmental placement at MWU

\begin{tabular}{|c|c|c|c|c|c|c|c|c|}
\hline \multirow[t]{2}{*}{ Items } & \multirow[t]{2}{*}{ Option } & \multicolumn{2}{|c|}{ students } & \multicolumn{2}{|c|}{ officials } & \multicolumn{2}{|c|}{ Instructors } & \multirow{2}{*}{$\begin{array}{l}\text { Mean } \% \\
X^{-}\end{array}$} \\
\hline & & f & $\%$ & f & $\%$ & f & $\%$ & \\
\hline \multirow{4}{*}{$\begin{array}{l}\text { Are there criteria that governing } \\
\text { students' placement across different } \\
\text { study programs at your institution }\end{array}$} & $\mathrm{Y}$ & 67 & 28.8 & 13 & 76.5 & 8 & 50 & 43.33 \\
\hline & $\mathrm{N}$ & 11 & & & 11.7 & 5 & 31.2 & 5.33 \\
\hline & IDK & 155 & 4.8 & 2 & 11.8 & 3 & 18.8 & 53.33 \\
\hline & $\mathrm{T}$ & 233 & 33.6 & 15 & 100 & 16 & 100 & \\
\hline \multirow{4}{*}{$\begin{array}{l}\text { What are the sources of the criteria } \\
\text { employed to place students to different } \\
\text { departments at your institution }\end{array}$} & $\mathrm{MoE}$ & 9 & 3.9 & 3 & 17.6 & 3 & 18.75 & 5 \\
\hline & MW & 2 & 0.9 & 9 & 52.9 & 4 & 25 & 5 \\
\hline & UD & 222 & 92.2 & 5 & 29.4 & 9 & 56.25 & 79 \\
\hline & $\mathbf{T}$ & 233 & 100 & 17 & 100 & 16 & 100 & \\
\hline \multirow{3}{*}{$\begin{array}{l}\text { Were students provided with the } \\
\text { brochure containing information about } \\
\text { the available courses including how to } \\
\text { choose area of students' interests }\end{array}$} & $\mathrm{Y}$ & 30 & 12.8 & 5 & 29.4 & 1 & 6.2 & 12 \\
\hline & $\mathrm{N}$ & 203 & & 12 & 70.6 & 15 & 93.8 & 79.66 \\
\hline & $\mathbf{T}$ & & 87.2 & & 100 & 16 & 100 & \\
\hline \multirow{4}{*}{$\begin{array}{l}\text { Was the brochure if any, clear, to direct } \\
\text { students to choose department of their } \\
\text { interests. }\end{array}$} & $\mathrm{Y}$ & 10 & 4.6 & 3 & 17.6 & 1 & 6.2 & 4.66 \\
\hline & $\mathrm{N}$ & 20 & 9.2 & 2 & 11.8 & 0 & 0 & 7.33 \\
\hline & UD & 203 & 87.2 & 12 & 70.6 & 15 & 93.8 & 76.66 \\
\hline & $\mathrm{T}$ & 233 & 100 & 17 & 100 & 16 & 100 & \\
\hline $\begin{array}{l}\text { Is there a career counseling services that } \\
\text { can help students to make them better } \\
\text { choices at your university }\end{array}$ & $\begin{array}{l}\mathrm{Y} \\
\mathrm{N} \\
\mathrm{T}\end{array}$ & $\begin{array}{l}18 \\
215 \\
\mathbf{2 3 3} \\
\end{array}$ & $\begin{array}{l}7.3 \\
92.7 \\
\mathbf{1 0 0}\end{array}$ & $\begin{array}{l}3 \\
14 \\
\mathbf{1 7} \\
\end{array}$ & $\begin{array}{l}17.6 \\
82.4 \\
100 \\
\end{array}$ & $\begin{array}{l}- \\
16 \\
\mathbf{1 6}\end{array}$ & $\begin{array}{l}- \\
100 \\
\mathbf{1 0 0}\end{array}$ & $\begin{array}{l}7 \\
82.66\end{array}$ \\
\hline $\begin{array}{l}\text { Do you believe the departmental } \\
\text { placement criteria of your institution } \\
\text { implemented effectively }\end{array}$ & $\begin{array}{l}\mathrm{Y} \\
\mathrm{N} \\
\mathrm{T}\end{array}$ & $\begin{array}{l}32 \\
201 \\
\mathbf{2 3 3}\end{array}$ & $\begin{array}{l}13.7 \\
86.3 \\
100\end{array}$ & $\begin{array}{l}9 \\
8 \\
17\end{array}$ & $\begin{array}{l}53 \\
47 \\
16\end{array}$ & $\begin{array}{l}6 \\
10 \\
\mathbf{1 6} \\
\end{array}$ & $\begin{array}{l}37.5 \\
62.5 \\
\mathbf{1 0 0}\end{array}$ & $\begin{array}{l}15.66 \\
70\end{array}$ \\
\hline
\end{tabular}

Note: $F=$ Frequency, $\%=$ Percentage $N=$ No, $Y=Y e s, I D K=I$ don't know, MoE=Ministry of Education, $M W U=$ Madda Walabu University, $U D=$ Undecided.

Table 1 above shows that majority $155(66.5 \%)$ of 233 students replied they knew nothing about the presence of the criteria while, $13(76.5 \%)$ of 17 officials and $8(50 \%)$ of 16 instructors reacted there was criteria governing students' placement into different study programs at their university. The response of $(\mathrm{N}=13)$ officials and $(\mathrm{N}=8)$ instructor response to of open-ended item, the responses of $67(28.8 \%)$ student respondent and the result of document consultation confirmed the presence of adopted criteria guiding student's placement into various departments at the targeted university. Accordingly, most of the officials' and some of the instructors who agreed the presences of the criteria principal for department placement pointed the criteria as follow in the open-ended item:

The theoretical criteria adopted at this university for placement of students were: (i) Vacancy available in each department, (ii) the score in (NHEEE) of candidates wishing to enter the same educational programs, (iii) the candidates' ranking of educational programs (choices rank) (iv) special requirements of the candidate (male, female, physically disability and developing region where students with such special requirement placed into the department they wish at first choice).

Students were also requested to list the criteria by which they placed into their department and few students $(\mathrm{N}=67)$ noted the criteria as "National Higher Education Entrance Examination (NHEEE) score and Ethiopian General Secondary Certificate Examination (EGSECE) score"

The MWU legislation document was consulted and it was in line with the responses of officials' instructors than students. Article 39(P: 67 of 127) of this document stipulated that the students' departmental placement criteria as follows:

1. Students will be admitted into the program of their choices on a competitive basis using their grade as a measure. However special provisions shall be for female students and other socially disadvantaged group that require affirmative action.

2. Academic units may submit specific entrance requirements such as passed exam in certain subjects or additional test results and my state if, and what kinds of physical disabilities prevent students from pursuing studies in their respective disciplines. These requirements need to be developed by the relevant academic units and approved by the APC the senate.

However, this document could not identify which grade would be used to decide a student's study program. Regarding the source of the criteria almost all 222(92.2\%) of students have no opinion whereas $9(52.9 \%)$ of 17 officials and $4(25 \%)$ of the 16 instructors reacted it was established by MWU. Here, one can understand that 
students had limited knowledge about the criteria by which they were placed into their department. The Madda Walabu University legislation document stipulated in its article 39(P: 67 of 127) that "the criteria was worked out by Academic Standard and Quality Assurance Committee (ASQAC) and tailored by the department heads for use" Most students interviewees told that, "we did not take any test" when they were asked, if they were evaluated by selection examination and interviewed during their placement into their department. Majority of the official interviewees confirmed students' response regarding the utilization of students 'selection examination and interview as placement criteria when they told, "We never used such test to select students' to different department", when asked if they have ever used selection examination and interview as placement criteria. The Madda Walabu University legislation document was investigated and in its article 39 No- 7 this document described the issue about selection examination and interview as follows:

When there are more applicants with same grade indicating the same level of preference to a program than place therein applicant with better in the specific entrance requirements shall be given priority (pp69 $N_{0} 7$ ).

One can understand from this that, this legislation document was not practical to govern for students' departmental placement. Also, the study further indicated that the students have no information about the criteria governing their placement to their department. This study revealed that criteria adopted at Madda Walabu University for students' departmental placement were: (i) Vacancy in each department, (ii) the rank of the score in (NHEEE) of candidates wishing to enter the same educational programs, (iii) the candidates' ranking of educational programs (choices rank) (iv) special requirements of the candidate (male, female, physically disability and being from developing region like was Gambella, Somale, Afar and Benishangul ) where students from those region given the opportunity to join department of their own first choices

The Experience from Turkey Higher Education Institution, the objective of students Selection and Placement in to different academic studies was to select and place students with highest possibility of success in all available programs taking in to consideration their preferences and performances ("OSYM ,2006). The criteria for placement of students in to different program in the higher education institution in Turkey, according to "OSYM (2006), were: (i) the quota, that is, the maximum number of students to be admitted to each educational program (ii) the rank of the score of candidates wishing to enter the same educational programs (iii) the candidates' list and ranking of educational programs (iv) special requirements of the candidate (male, female) (OSYM, 2006). These criteria were similar with that of MWU in the elements but that of MWU as indicated in this finding lack implementation.

Table 1. above indicated that different respondents (students, instructors and officials) were asked if students were provided with the brochure containing information about the available courses either in paper format or their university website and if students received career counseling which helped them in making better choices as well as if placement criteria and practice were implemented effectively. Accordingly, as far as provision of brochure is concerned, most of respondents, that is 203(87.2\%) of students, 12(70.6) of officials and $15(93.8 \%)$ of instructors reacted, there was no provision of brochure containing information about the available study programs, neither in paper format nor an online version on their university websites. Documents were checked and a document named as Oda was found containing information about MWU. This document was published by MWU at the end of each academic year, during students' graduation ceremony. Students were interviewed to check whether they have an access to this document (Oda) as brochure and most of them told that, "The document is prepared and distributed exclusively to the staffs of the university and it is not available to us" This confirmed the responses of all participants (students, officials and instructors) regarding provision of brochure that inform students about the MWU. The study by Ayalon and Abrham (2002) stated that, knowledge about the higher education and its system helps students in making right choices during department choices and acquires the advantage they postulate to gain at their university studies. Nakpodia, (2009) described that, the main characteristics of a learning organization are: learning culture, free exchange and flow of information, commitment to learning, valuing people, climate of openness and trust and learning from experience.

As far as career counseling service concerned, 215(92.7\%) of 233 students, $14(82.4 \%)$ of 17 officials and all 16 (100) of instructor respondents replied there were no career counseling service helping students in making better choices during application for their study program. The students' response in open -ended item shows that, the department heads and faculty deans gave them orientation about their faculty and department. This orientation according to the students' responses was, more of advertisements aimed to attract applicants and nonof advices on how to help students to make better choices. The students reported this condition as follows, "We do not know about the entry requirements for a particular department and the likely Higher Education Entrance Examination (HEEE) scores we were expected to have to get place in the department of our first choices"

Regarding the entry requirements for a particular department, officials were asked and most of them reported the requirement as: "Better scores in HEEE and students' interest". However nothing was detailed in the legislation document of the MWU regarding this issue. This indicted that students have no information regarding requirement and how they were placed to their department at the targeted University. It needs the students to get 
pre-admission counseling to make better choices in the process of placement into their academic study. Some elements of pre-admission counseling of students were described by Chauhan (1982 in Yikunoamlak 2000), as follows:

The process (counseling services for selection and placement of students into different programs of studies need to consist:(1) Explain the general characteristics of each field (2) Orientation about some vocational fields which students have no enough educational experience (3) Enabling the students to understand their own interest, aptitude and to relate to field of study under their study and the actual placement services which deal with actual choice of an educational study.

However, this counseling service was not the case in students' departmental placement process at the targeted university where students' respondents received no advice when they were selected to their academic study. The FDRE Higher Education Proclamation (No. 64/2009) is the law that guide all higher institution in the country (Ethiopia) and regarding pre-admission counseling of students on study choice it has clearly stated that: All institutions of higher education shall explore and establish a necessary system of preadmission counseling of students on study choice, every institution, through its relevant units and academic staff, shall officially and properly inform students and applicants of the courses of study available courses of study, the content, structure, and requirements of each course (FDRE Higher Education Proclamation No. 64/ 2009).

One can understand from the above finding that, this Higher Education Proclamation was not in practice at MWU as far as the necessary system of pre-admission counseling of students on study choices in concerned . This raise series question on the appropriateness of departmental placement practices as adequate guidance and information sources about department choices was absent at this university. Researchers like, Morante, 1987; Wattenbarger and McLeod in Victoria (2008) stated that, multiple measures, such as standardized test results, performance in select courses, and students' interest, and High School GPA's, as well as supportive actions like career guidance and information sources, appeared to supplement departmental placement criteria designed to make placement decision. According to Bordon and Fu (2003) in college effective and appropriate criteria providing necessary information about candidates is to be used during admissions so that, one can select population of students' according to their preferences and performances.

Regarding effective implementation of adopted, departmental placement criteria, 201(81.6\%) of students, $8(47 \%)$ of officials and $10(62.5 \%)$ of instructors' respondents replied the criteria were not implemented effectively. Regarding this the official interviewees stated as follows:

During placement of students into various departments vacancies and HEEE score were more used by placement committees than the other criteria adopted. If we implement all criteria and place students as per declared in the legislation document, some departments would be left vacant and could be closed. Thus, the only choice is to assign some students out of their best choice at our university.

The overall finding of this study shows that, supportive actions like career counseling and brochure helping students in their choice process were absent at the targeted university. Most of this criterion adopted for students. department placement purpose were idle since only two of its elements, as vacancies available in each department and HEEE score were exclusively dominating departmental placement practice. This study thus, shown o that, there was a problem regarding effectiveness and practicality of the practice, policies, procedures and criteria that has adopted for students' department placement at MWU.

\subsection{Factors influencing of Students Department Placement Practice at MWU}

This section presents the analysis of qualitative and quantitative data obtained from different selected type of respondents as well as the results obtained from consultation of documents. In this regard, the following table 4 the influences of the Criteria and Practice of departmental placement on students' choices of different departments at their university. 
Table 2 Influences of the Criteria and Practice of Departmental Placement on

Students' Choices of Different Departments

\begin{tabular}{|c|c|c|c|c|c|c|c|c|c|c|}
\hline \multirow{2}{*}{$\mathbf{S} / \mathbf{N}$} & \multirow[b]{2}{*}{ Items } & \multirow[b]{2}{*}{ Options } & \multicolumn{2}{|c|}{ Students } & \multicolumn{2}{|c|}{ Officials } & \multicolumn{4}{|c|}{ Instructors } \\
\hline & & & f & $\%$ & f & $\%$ & f & $\%$ & $\chi$ & \\
\hline \multirow[t]{4}{*}{1} & Does your university offer a & $\mathrm{Y}$ & 144 & 64.5 & 7 & 38.70 & 7 & 41 & \multirow{4}{*}{$\begin{array}{l}\chi^{2=} \\
34.45\end{array}$} & 0.34 \\
\hline & wider range of departments & $\mathrm{N}$ & 84 & 61.8 & 7 & 41.2 & 7 & 43.8 & & \\
\hline & that can provide you more & IDK & 5 & 2.2 & 0 & 0 & 3 & 17.7 & & \\
\hline & choices? & $\mathbf{T}$ & 233 & 100.0 & 17 & 100 & 16 & 100 & & \\
\hline \multirow[t]{4}{*}{2} & were students given lists of & $\mathrm{Y}$ & 141 & 60.5 & 15 & 88.2 & 12 & 75.0 & & \\
\hline & departments & $\mathrm{N}$ & 84 & 37.3 & 2 & 11.8 & 1 & 6.25 & \multirow[t]{3}{*}{4.99} & .030 \\
\hline & related to your preparatory & IDK & 5 & 2.2 & 0 & 0 & 3 & 18.75 & & \\
\hline & $\begin{array}{l}\text { school course when you } \\
\text { placed to your department }\end{array}$ & $\mathbf{T}$ & 233 & 100 & 17 & 100 & 16 & 100 & & \\
\hline \multirow[t]{9}{*}{3} & Does the criteria of & $\mathrm{Y}$ & 23 & 9.9 & 11 & 64.7 & 6 & 37.5 & \multirow[t]{4}{*}{2.332} & \multirow{4}{*}{$\begin{array}{l}.506 \\
.065\end{array}$} \\
\hline & departmental placement & $\mathrm{N}$ & 210 & 90.1 & 6 & 35.3 & 7 & 43.8 & & \\
\hline & used at your university & IDK & 5 & 2.2 & 0 & 0 & 3 & 18.75 & & \\
\hline & $\begin{array}{l}\text { provide students chance to } \\
\text { choose wide range of } \\
\text { departments }\end{array}$ & $\mathbf{T}$ & 233 & 100 & 17 & 100 & 16 & 100 & & \\
\hline & How far it is possible for all & AW & 5 & 2.2 & 3 & 17.7 & - & - & \multirow[t]{5}{*}{5.759} & \\
\hline & students to join their & $\mathrm{ST}$ & 98 & 42.0 & 12 & 70.5 & 8 & 50.0 & & \\
\hline & department according to & $\mathrm{Rl}$ & 105 & 45.1 & 2 & 11.8 & 2 & 11.5 & & \\
\hline & their own first choices at & NAA & 30 & 12.9 & 0 & 0 & 6 & 37.5 & & \\
\hline & your university & $\mathbf{T}$ & 233 & 100 & 17 & 100 & 16 & 100 & & \\
\hline \multirow[t]{4}{*}{5} & Do you know students who & $\mathrm{Y}$ & 22 & 95. & 12 & 70. & 1 & 87. & \multirow[t]{4}{*}{4.813} & \multirow[t]{4}{*}{.090} \\
\hline & limited by the departmental & $\mathrm{N}$ & 3 & 7 & 29. & 5 & 4 & 5 & & \\
\hline & placement practices and & $\mathbf{T}$ & 10 & 4.3 & 5 & 82.2 & 2 & 11.5 & & \\
\hline & $\begin{array}{l}\text { criteria to join their } \\
\text { department to according } \\
\text { their own keen interests }\end{array}$ & & 233 & 100 & 17 & 100 & 16 & 100 & & \\
\hline \multirow[t]{3}{*}{6} & Do you think department & $\mathbf{Y}$ & 23 & 10 & 6 & 35 & 3 & 15 & \multirow[t]{2}{*}{12.93} & \multirow[t]{3}{*}{.113} \\
\hline & placement practices is & $\mathbf{N}$ & 210 & 90 & 11 & 65 & 13 & 85 & & \\
\hline & effective at your University & $\mathbf{T}$ & 233 & 100 & 17 & 100 & 16 & 100 & $\mathrm{Df}=8$ & \\
\hline
\end{tabular}

Note: $\%=$ Percentage $=$ Frequency, $\mathrm{Y}=\mathrm{Yes}, \mathrm{N}=\mathrm{NO}, \mathrm{IDK}=$ don't know, $\mathrm{AW}=\mathrm{Always}, \mathrm{ST}=$ Sometimes, $\mathrm{Rl}=\mathrm{Rarely}$, $\mathrm{NAA}=$ Not at all, $\mathrm{T}=$ Total,

As indicated in table 23above, students, officials and instructor respondents were asked, if their university give provides students the chance to choose their academic study among wide range of different during department placement, if the criteria and practice by which students placed to their department is open to provide students possibility of choosing their study program from wide range of departments, if the they(officials and instructors) know students who limited to join their department to according their(students) own keen interests by the departmental placement practices and criteria, to judge the students freedom to choose their study program according to their best interests.

Accordingly, the majority, $144(61.8 \%)$ of student, 7(41.2\%) of officials and 7(43.8\%) of instructor's respondents replied their university offer a wider range of programs that can provide students more choices while few $84(36 \%)$ students, $10(58.8 \%)$ officials and some $6(37.5 \%)$ instructors replied their university was not offering in a wider range of study programs that can provide students more choices. The chi-square result $\chi^{2}$ $=4.123$, with $\mathrm{df}=2$, at $\mathrm{P}=.127$ at $\alpha=.05$ level of significance. The calculated $\mathrm{p}$-value is greater than .05 , i.e. there is no significant difference between the responses of students, officials and instructors. Officials were interviewed to tell the major factors that limit students' chances to choose their academic study from wide range of department and told as follows:

At our university it is open for students to choose the study program of their interest but the chance to be admitted into the academic study of their first preferences is rare since it is determined by their HEEE score.

The response difference might be due to individual difference in their expectation about the development of the university in its program of study and the number of study program was found slightly good to enhance students' choices when the student's application leaf investigated. 
Table 3 above also indicate that some $87(37.3 \%)$ of students, many $15(88.2 \%)$ of officials and many $12(75 \%)$ of instructor respondents replied that students were given lists of different study programs whereas many 141(62.7) students and very few officials replied students were not given lists of different departments when asked if students were given lists of different departments related to their preparatory school courses during their placement to their departments. But, according to departmental placement principle students are supposed to got access to lists of different departments related to their preparatory school courses during their placement to their departments. In this respect, the observed, $\chi^{2}=0.011$, with $\mathrm{df}=1$ at $\mathrm{P}=.917$, at $\alpha=.05$ level of significance, no significant differences in the responses of the three groups i.e Officials instructors and students' responses. The application leaf also confirmed that students given lists of different study programs. This study verified that although lists of different departments given to students, probability of joining department by their interests was rare as the majority $210(90.8 \%)$ of student, some $6(35.3 \%)$ of official and some $7(43.8 \%)$ of instructor respondents replied the criteria and practice minimize students' chances when asked if the criteria by which students placed to their department provided students the chances to choose wide range of departments.

When they were asked about the influences of the criteria governing departmental placement practices on their interests, most of the students reported that; they were dissatisfied with their department and practices by which they selected to their study program. All respondents were asked if they know students who limited by the departmental placement practices and criteria to join their department to according their own keen interests. Consequently, majority $223(95.7 \%)$ of the students, 12(70.5\%) of officials and $14(87.5 \%)$ of instructor have seen when students limited their chances to join department of their keen interests. The observed chi-square shows that there is no statistical significance difference for this item between the views of the respondents as $\chi^{2}$ $=3.732$, with $\mathrm{df}=2$, at $\mathrm{P}=.155$ at $\alpha=.05$ level of significance. With respect to this, (Barnett,1992), strongly argued that students' placement demands the establishments of an institutional culture that is quality management in which each professional is seized of his or her responsibilities and take care over all his or her own professional efforts. Therefore, this point agrees with the assumption that, the instructors have the right to comment on academic affairs for further progress of the college. If not, as it was revealed by the study, its impact results in decrease of quality training. All students asked to provide their suggestion as solution to the problems of departmental placement practice at their university in the open-ended item and majority of them noted their suggestion as follows:

Ministry of Education need to establish identical criteria which will be used for students' departmental placement and set alienated unit enforcing its implementation within the university. The concerned bodies at the targeted university need to review and discuss with each other about the practice in use for departmental placement so as to enhance students' chances and interests to join their study program.

From the student's response one can deduce that the students are the main customer of the university were dissatisfied with the placement practice of their institution. Observed, $\chi^{2}=12.93$ with $\mathrm{df}=8$ at $\mathrm{P}=.113$ when $\alpha=.05$; the responses have no significant difference.

Thus, from this finding one can understand that students were provided choices but opportunity of joining the department they wish at most was not in promising condition and student assigned into department out of their keen interests. This reflects that the departmental placement criteria and practice has influences on students' choices of department at the targeted university. The existing research shows that the experiences of uncertainty during first year, poor motivation, a perception of unpreparedness and misplaced expectations have all been found to be associated with student attrition in higher education (Chalmers, 2008).

\subsection{The level to which the Students have the chances to join the Departments of their Interests at MWU}

In an educational setting, student belief of whether a particular curriculum area is important for their future life or not are often derived from their interests. Whether belief and expectations of a student are supported by the significant practices in their institution is likely to have an important impact on the formation of student's selfesteem, academic behavior, academic performance, and perhaps other educational outcomes (Shavelson et al., 2004). Here students' interests and the extent to which placement criteria and practice maintains their interests, would have substantial impacts on the outcomes under consideration (students learning and academic performances). Based on the above perspective, this section presents the analysis of quantitative and qualitative data obtained from students, officials and instructors as well as documents regarding criteria and practice experienced to preserve students' choices during students' selection into different departments at the targeted university. The following table 3 shows the data obtained from all respondents regarding the degree to which students' interests to join their departments by their most preferences maintained at the targeted University 
Table 4. The degree to which chance of joining departments by students interests maintained

\begin{tabular}{|c|c|c|c|c|c|c|c|c|c|}
\hline \multirow[b]{2}{*}{ No } & \multirow[b]{2}{*}{ Items } & \multirow[b]{2}{*}{ Options } & \multicolumn{2}{|c|}{ Students } & \multicolumn{2}{|c|}{ Officials } & \multicolumn{2}{|c|}{ Instructors } & \multirow[t]{2}{*}{ Mean } \\
\hline & & & f & $\%$ & $f$ & $\%$ & $f$ & $\%$ & \\
\hline \multirow[t]{3}{*}{1} & \multirow{3}{*}{$\begin{array}{l}\text { Do you think the practice of departmental } \\
\text { placement employed at your university to } \\
\text { place students to different departments } \\
\text { maintains the students choices }\end{array}$} & $\mathrm{Y}$ & 102 & 47.8 & 12 & 70.5 & 6 & 37.5 & 0.8 \\
\hline & & $\mathrm{N}$ & 131 & 56.2 & 5 & 29.5 & 10 & 62.5 & 0.9 \\
\hline & & $\mathbf{T}$ & 233 & 100 & 17 & 100 & 16 & 100 & $\mathbf{0}$ \\
\hline \multirow[t]{4}{*}{2} & \multirow{4}{*}{$\begin{array}{l}\text { The extent to which the interests of } \\
\text { students to be placed to their departments } \\
\text { by their first choice maintained at your } \\
\text { institution is }\end{array}$} & $\mathrm{H}$ & 20 & 6.0 & 2 & 11.8 & 4 & 25.0 & 0.2 \\
\hline & & $\mathrm{M}$ & 103 & 44.2 & 10 & 58.8 & 4 & 25.0 & 0.75 \\
\hline & & $\mathrm{L}$ & 110 & 47.2 & 5 & 29.4 & 8 & 50.0 & 0.8 \\
\hline & & $T$ & 233 & 10 & 17 & 0.0 & 16 & 100 & \\
\hline \multirow[t]{4}{*}{3} & \multirow{4}{*}{$\begin{array}{l}\text { Do you think that the practice for students } \\
\text { departmental placement employed at your } \\
\text { institution maintaining choices of all } \\
\text { students }\end{array}$} & $\mathrm{AW}$ & 24 & 10.3 & 2 & & 3 & 18.7 & 0.2 \\
\hline & & ST & 89 & 38.2 & 5 & 29.5 & 5 & 31.3 & 0.6 \\
\hline & & NA & 120 & 50.5 & 10 & 58 & 8 & 50.0 & 0.9 \\
\hline & & $\mathbf{T}$ & 233 & 100 & 17 & 100 & 16 & 100 & \\
\hline \multirow[t]{4}{*}{4} & \multirow{4}{*}{$\begin{array}{l}\text { Is it possible for all students to join the } \\
\text { departments of their first choice } \\
\text { regardless of their s Entrance examination } \\
\text { scores }\end{array}$} & $\mathrm{Y}$ & 20 & 6.0 & 7 & 41.2 & 3 & 18.7 & 0.2 \\
\hline & & $\mathrm{N}$ & 204 & 94.0 & 10 & 58.8 & 13 & 81.3 & 1.5 \\
\hline & & $\mathbf{T}$ & 233 & 100 & 17 & 100.0 & 16 & 100 & \\
\hline & & $\mathrm{Y}$ & - & 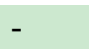 & 17 & 10 & 14 & 87.5 & 0.2 \\
\hline \multirow[t]{2}{*}{5} & \multirow{2}{*}{$\begin{array}{l}\text { Did you heard students complaints about } \\
\text { misplacement to their departments }\end{array}$} & $\mathrm{N}$ & - & - & 0 & & 2 & 12.5 & 0.001 \\
\hline & & $\mathbf{T}$ & - & - & -17 & 100.0 & 16 & 100 & \\
\hline \multirow[t]{3}{*}{6} & \multirow{3}{*}{$\begin{array}{l}\text { If there were measures taken to respond } \\
\text { students complaints }\end{array}$} & $\mathrm{Y}$ & 10 & 3.0 & 4 & 23.5 & 2 & 12.5 & 0.1 \\
\hline & & $\mathrm{N}$ & 223 & 97.0 & 13 & 76.5 & 14 & 87.5 & 1.6 \\
\hline & & $\mathbf{T}$ & 233 & 100 & 17 & 100.0 & 16 & 100 & \\
\hline \multirow[t]{3}{*}{7} & \multirow{3}{*}{$\begin{array}{l}\text { If a student fulfilled the requirements, } \\
\text { assigned to department out of his /her } \\
\text { interest at your institution, is it possible to } \\
\text { change the mistake }\end{array}$} & Y & 28 & 12.0 & 3 & 17.6 & 2 & 12.5 & 0.2 \\
\hline & & $\mathrm{N}$ & 205 & 88.0 & 14 & 82.4 & 14 & 87.5 & 1.5 \\
\hline & & $\mathbf{T}$ & 233 & 100 & 17 & 100 & 16 & 100 & \\
\hline
\end{tabular}

Note: $F=$ Frequency, $\%=$ Percentage, $Y=$ Yes, $N=N O, A W=$ Always, $S T=$ Sometimes,

$N A A=$ Not at all, $H=$ High, $M=$ Moderate, $L=L o w, T=$ Total.

The result in table 4 above indicated that majority, $131(56.2 \%)$ of students, $5(29.5 \%)$ of official and 10 $(62.5 \%)$ of instructor respondents replied, the practice employed at their university do not maintains the students' choices while, $102(47.8 \%)$ of students, $12(70.5 \%)$ of instructors and 6(37.5\%) instructors replied students' choices to be placed into their departments maintained. Regarding the level to which the choices of students to be placed into their department on basis of their first choices maintained, majority $110(47.2 \%)$ of students, some $5(29.4 \%)$ of official and half $8(50 \%)$ instructor respondents rated students' interests less maintained. Students interests was moderately maintained as responses of some $103(44.2 \%)$ of the students, majority $10(58.8 \%)$ of the official and few $4(25.0 \%)$ of the instructors. To substantiate the responses "less maintained" and "moderately maintained" by different participants regarding this issue, all of them were asked whether choices of all students to join their study program by their first choices maintained. Accordingly, majority $120(50.5 \%)$ of the students, majority $10(58.8)$ of the officials and half $8(50 \%)$ of the instructors replied the interest of all students was not maintained at all.

In an attempt to check this' response, officials were interviewed to tell the main reason for which students' students' choices to join their department not maintained and three of these officials' interviewees told as here under:

At our university, there are cases where the numbers of student wishing to be admitted into same department become more than the capacity of places designed to admit them in contrast there are other cases where some department wished by fewer students than the place designed to admit them. In such situation we manage students' placement by comparing their HEEE score and consequently those having better HEEE score got place in the department they wished at their first choices whereas those possessing lower HEEE score, assigned into their second, third and etc, going down in their choice hierarchy and place available. Accordingly, there was a condition where students could be assigned into their ninth or tenth choice based on the department presented for choices. This is the challenge to maintaining students' choices.

As a result, many Ethiopian university graduates have been facing unemployment. One of the students' interviewees who was studying Amharic department told that he is prismatic as he 
going to lead a life of the unemployed in because he was placed in a department that was a far cry from his choice. "I want to study Civics. But they placed me in Amharic department which is the farthest thing from my favorite list.

When asked, if there is a possibility in which, all students can join their departments by their first choices regardless of their HEEE score, majority 204(94\%) of students, 10(58.8\%) officials and 13(81.3\%) of instructors reacted that it was impossible. Two type of respondents (officials and instructors) were asked, if they ever heard students complaints about that they lose their first choices departments and all $17(100 \%)$ of the officials and almost all $14(87.5 \%)$ of the instructors replied they heard students complaints regarding the issue. To substantiate this response MWU Legislation was explored and it depicted the issue in its article 39 as follows:

An applicant who has doubt that there was an error in the placement may report the case to the academic unit and the university registrar for review. The academic unit, through the university registrar shall report to the senate all admission and placement made in the university ( $p p 69$, № 9).

To check the practicality of this document, all (students, officials and instructors) respondents were asked, if they know any measure taken to correct the mistake of misplacement and almost all $223(97.0 \%)$ of the students, majority $13(76.5 \%)$ of the official and many $14(87.5 \%)$ of the instructor respondents replied there was no action taken to correct the issue. The result obtained from students' respondents through open ended questionnaire validated the non-practicality of the legislation document regarding response for students' complaint about their departmental placement problem.

Students were also asked, the option they have when there is no positive response for their complaints and some of them reported that they were studying what they were assigned by their faculty deans and department heads to study whereas, other reported that to search friends who have same dissatisfaction in related department to exchange with was the option they have. Martha and Charles (2005) stated that, "Department chairs and faculty deans can positively or negatively influence student interests for a field -- some compelling department chair can get students engaged in fields that they previously disliked". All respondents were asked about the possibility of correcting the mistake, if students fulfilling the criteria of department placement assigned to the department out of his/her first choice, majority 205(88\%) of the students, $14(82.4 \%)$ of officials and $14(87.5 \%)$ of the instructor respondents replied, it was impossible to correct such mistake. Instructors and officials (university managers) of the targeted university asked through open-ended item to state the reasons for which correcting the mistake impossible and some of the officials and majority of the instructors' participants put the reasons in the open-ended item of questionnaire as follows:

In some cases, all students learning in one department may be found to be those assigned in that department without their first choices since getting place in department by own first choice was determined by the place existing in each department. If we try to correct such mistake some study programs might left unoccupied. That is why it is impossible to correct.

The students' responses to same open-ended item show that; they found each faculty and department heads striving to fill the vacancies in the department they were head Without inspection of who is wrongly located and who is rightly located. Here one can understand that the legislation document designed to govern all practice was not practical concerning students' placement into various department at the targeted university. This study also revealed that shortage of vacancies in most chosen departments, reluctance of the university managers to close those non-selective departments. The attention of faculty and department heads during students' selection and placement of students into different department was concentrated on filling the existing vacancies. Consequently, underprepared students were forced to study in the department difficult to them and which may not gratify students in pursuit of a successful career. The interview result of one of the students interviewees transcribed as hereunder:

I forcibly placed into the History department, had that had he been placed in the department of his choice, apart from standing on his feet, he could have contributed a lot to his family and nation. Besides, he would not become an addict and a burden to the society. "As an option, I thought to pursue my education enrolling in private colleges in Addis Ababa, but the tuition fee was too high to pay. Hence, I couldn't realize my dream of being Sociology. I regret not to able to contribute for my country qualifying in the profession I love.

Moreover, I have been subjected to different health problems, " he stated, placing students based on their preference and their health condition should be given priority. As far as I am concerned, I would have been effective, if I had gotten the chance of studying a field of my choice. Every student would be successful if s/he is placed in a department s/he chooses." Another interviewee who was placed for his part says the incongruity of student's interest and their placement has been affecting their future life. "I was not happy when I learnt my placement in field, while my dream was to be an engineer. I couldn't be able to work in the field I graduated with due to workplace remoteness and other factors. I always feel sad for not 
being lucky to exploit my talent," he points out.

He admits that the mismatch of the student's interest and the actual placement has caused graduates to lose hope in their life and many of them have been taken adrift into addiction.

"Nowadays, we can see young university graduates who spend their golden time chewing khat.

Due to this reason, several of them have been confronted by health problems. This could affect the socio-economy of the nation since it is losing a productive labor force. Hence, the government should give attention for this issue,

One of the official interviewees insists that:

"government has identified the problem and it has been working to address it. "The problem raised by the student is evident. Many youths are in frustration due to improper placement. They are not joining departments as per their choice, 'he said. "What aggravates the problem is the fact that nation's job opportunity is very limited"

"It couldn't be compatible with the increasing number of populations. Besides, there is not linkage between industry and universities. The official internee made it clear that NEAEA has planned to assign students based on two basic considerations. The one and the main criteria for placement will be based on the grade they get during national examination and the second criteria will be the student's interest. According to this official interviewee, the government has also been implementing 70/30 placement mechanism which paves a way for 70 percent of students to be assigned in natural science and 30 percent in social science fields, he reaffirmed. the government have been focusing on natural science fields since we prioritize for research and innovation."

Asked what shall be done to appropriate student placement, most of the interviewees stated that:

We need Ethiopian students to utilize their talent and skills so as to benefit their nation and family. The placement of students based on their interest would be encouraged and the government shall work on it, Ethiopia has been endeavoring to expand education to produce qualified human power.

5.5. Students placed to their departments by their own first choices and those Assigned without their First choices

Students usually take their ability into consideration when they choose departments/fields of study. They do such choices so that they can successfully complete courses and secure good jobs after graduation (Ayalon and Abraham, 2002). This implies that student's choice of study program is determined by the availability of good jobs which indirectly determine the student's career path for the rest of his/her life. Based on this background, this section analysis the number of students placed to their departments on the basis of their first choices and those assigned out of their first choice across eight departments at the targeted university. Consequently, the placement condition 233 students in their 1 st and $3^{\text {rd }}$ year studies in 2012/13 were used for this purpose. The following tables 6 below indicate the number of students placed /assigned into their department by their first choices and without their first choices across the eight departments.

Table 3. The number of Students' joined their department by their first choices and those without their first preferences across the eight departments

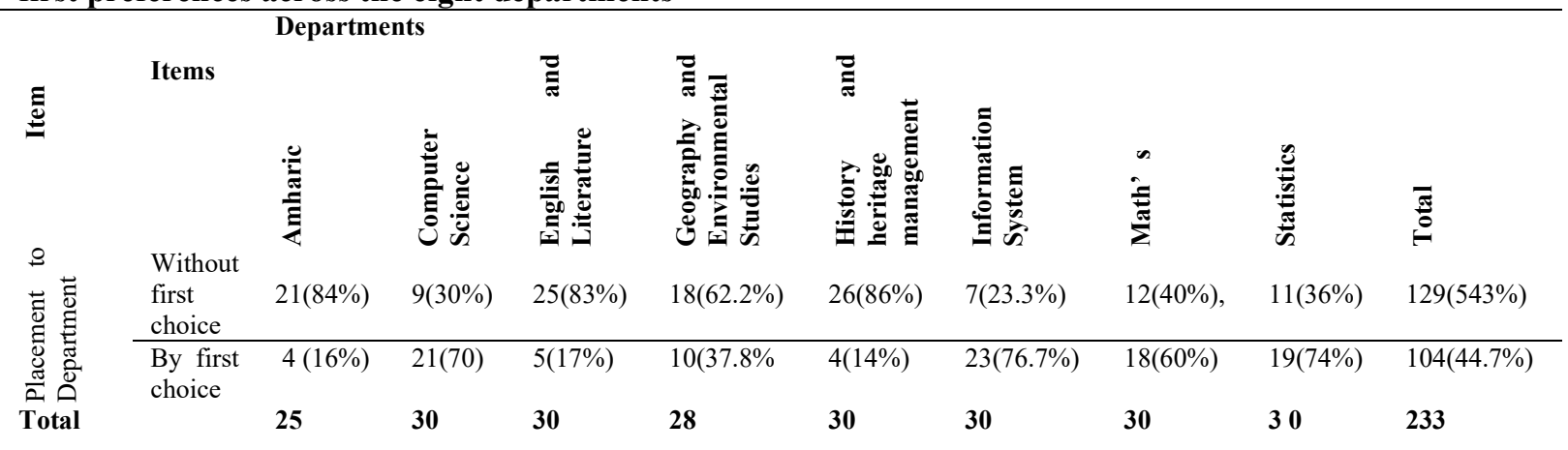

From the total number of 233 of the first- and third-year undergraduate batches of MWU their placement was analyzed. From a total of 233 students, 104 were placed into different departments by their first choice and the rest 129 students were assigned without their first choice (Table 8). If we see across the eight departments in table 6 above ,21 students out of 25 from Amharic department, 25(84\%) of 30 (83.3\%)students from English department, $9(30 \%)$ of 30 students from Computer science department, $7(23.3 \%)$ of 30 students from Information system department, 18 (62,2\%)of 28 from Geography department, 26((86.\%) of 30 students from 
history department, 11(11\%) out of 30 students from Mathematics department and 12(36\%) of 30 students from statistics department.

Most of those students assigned to their study programs without their first choices reported in open-ended item that, "they are feeling compelled to learn in our department" For a student to have the best opportunity to reach his potential, it absolutely essential that he be initially placed at the proper point in his remedial work (Victoria, 2008). Majority of the students' respondents from history, Amharic and English departments noted in open -ended item that' they were assigned to their departments by their 9th and 10th in choices order. Therefore, placement of students into their department without first choices was more serious in History and Amharic departments. The qualitative data obtained through open-ended items indicated that the majority of the students' respondents, except those learning in the four departments (Computer Science, Information system, Mathematics and Statistics), were attending their learning not out of their love for the profession but for other reasons such as desires for graduation and easily search other job. Students' interviewees among the misplaced students told this issue as "We are attending our field of study outside of our keen interests for the profession and we are ready to change our fields of study if we get other preferences". This indicated that if departmental placement was not one-time decision, most students would like to change their academic study. The overall finding of this study proved that, interests of students to choose their study program was not maintained to the extent that students' career and academic motive satisfied. Furthermore, this raise serious question about the academic performances of those students assigned out of their choice's priority at the university under this study. The finding by Jones (2011) in which he stated that, "in choosing their academic study, students may find themselves taking courses that are not a good match with their interests /personality and their grades may suffer as a result" is in line with this finding of this study. not like (Mrthas and Charles, 2005). As a result, hundreds of thousands of Ethiopians have been graduating from public and private higher institutions. However, the quality of education and placement of students beg for added attention

\section{Conclusions and Recommendation}

\subsection{Conclusions}

This study attempt was made to investigate the effectiveness practice students "placement into different departments at Madda Walabu University. Accordingly, based on the findings, the following conclusions were made:

(1)There were five criteria intended to govern departmental placement practices. However, the finding of this study revealed that, at MWU, the placement of students into different departments according to their first choice is possible as far as the number of first choice is less than or equal to the number of vacancies available in the department. Whenever the number of places available in departments is smaller than the number of students whose first choice is to be considered, such students are placed on the basis of their HEEE score. Thus, students with a higher HEEE score have had the advantage of being placed in departments according to their first choice. The remaining students have been placed in departments of their second, third, etc. preferences on the basis of the criteria set such as the availability of spaces, choice, developing region, and gender and HEEE score.(2)The finding of this study shown that, there is a gap in the implementation of the agreed criteria during students 'department placement process and some necessary criteria like placement test were left at MWU. (3) The other findings of this study indicated that, the students 'choices priority was not considered in the process of department placement at MWU and most students were learning in the academic studies they were assigned without their first choices. This study demonstrated that, majority of those students assigned into their academic studies without their first choices learning in Amharic and History departments at MWU.As such, it can be concluded that, it is difficult for those departments to educate and produce effective professionals from those students joining without their own keen preferences. This implies that, the department placement practice at MUW is not effective in placing students in department of their own keen preferences.

\subsection{Recommendations for Best Practices}

If it is to endeavor to expand education to produce qualified human power, the placement of students based on their interest would be encouraged and the government shall work so that, Ethiopian students to utilize their talent and skills so as to benefit their nation and family.

\section{Ensure transparency throughout the admissions process.}

Prospective students need to clearly understand how the admissions process works for all undergraduate, graduate, and professional programs. Universities should establish written admissions policies that outline expectations and requirements for admission to each program and list them on the university or program website. All necessary forms, academic records, letters of reference, and required standardized test scores should be clearly and accurately stated. Admissions policies should also outline the appeals process for those students that are denied admission, or clearly indicate that admissions decisions are final when no appeals process exists. Important deadlines, notification dates, and response dates should be publicly available and clearly stated. 


\section{Identify for prospective students the criteria used in holistic review.}

A list of criteria to be considered as part of the holistic review process should be included on the university/program website. Given the nature of holistic reviews and the difficulty in setting minimum standards for each criterion, programs should publish profiles of students admitted in prior years, including average standardized test scores. This information will provide prospective students with a basis for comparison when preparing their applications.

\section{Promote consistency in holistic reviews.}

Holistic review of applicants requires the balancing of academic accomplishments with personal attributes and characteristics. The goal when conducting holistic reviews, needs to be evaluating these criteria consistently and fairly. Evaluation rubrics should be developed to assist reviewers to objectively score the criteria. In addition, regularly training reviewers and routinely testing the reliability of reviewers will help ensure that the holistic review process is consistent from applicant to applicant.

\section{REFERENCES}

Abiy Zegeye, et al. (2009) Introduction to Research Methods (Preparatory module for Addis Ababa University graduate programs). Graduate Studies and Research Office. Addis Ababa University.

Adodo1, L and Gbore, O (2011). Prediction of attitude and interests of science Students' of different ability on their academic performance in basic science. International Journal of Psychology and Counseling Vol. 4(6), pp. 68-72.

Arfaei,K, et al. (2008). Assessing mid-wifery students' interest in their Career at medical sciences university in Tehran. Knowledge and Health. 3(1):2-32

ACT( Institutional Data FileNational collegiate dropout and graduation rates) (2003) Retrieved January 9, 2005, from http://www.act.org/path/postsec/droptables/index.html

Adodo1, L and Gbore, O (2011) Prediction of attitude and interests of science Students'of different ability on their academic performance in basic science. International Journal of Psychology and Counseling Vol. 2003. 4(6), pp. 68-72.

Allais, M. 19653) Le comportment de l'Homme rationnel devant le risque. Econometrica, 21(4): 503-546.

Anscombe, F. J., \& Aumann, R. J. (1963) A definition of subjective probability. Annals of Mathematical Statistics,,34(1): 199-205.

Afeti, G (2003) Promoting Change and Innovation in Tertiary Education: The Experience of HoPolytechnic, Ghana.

Arfaei,K, et al. (2008) Assessing mid-wifery students' interest in their Career at medical sciences university in Tehran. Knowledge and Health, 3(1):2-32

Ary,D, et al. 2(003) Introduction to Research in Education.6th ed. Australia: WADSWORTH.

Aslam,M(2013)International Journal of Business and Management 2003..www.ccsenet.org/ijbm .

Awasthi. I.C (2006) Education and employment market: a case study of Krishna district. Adult Education and Extension, 2(2), 47-80.

Ayalew Shibeshi, et al. (2009) Assessment of science education quality: Indicators in Addis Ababa, Bahir Dar, and Hawassa Universities. In Quality of Higher Education in Ethiopian Public Higher Education Institutions. Addis Ababa: Forum for Social Studies.2009.

Babad, E. (2014)Students' course selection: Differential considerations for first and last course. Research in Higher Education, 2(4): 469-492.

Babad, E., Darley, J. M., \& Kaplowitz, H. (1999) Developmental aspects in students' course selection. Journal of Educational Psychology ,(1): 157-168.

Babad, E., \& Tayeb, A. (2003)Experimental analysis of students' course selection. The British Journal of Educational Psychology,73(Pt 3): 373-393.

Baldwin, G., \& James, R. (2000). The market in Australian higher education and the concept of student as informed consumer. Journal of Higher Education Policy and Management, 2000,22(2):139-148.

Beard, R. E., Pentikainen, T., \& Pesonen, E. (1984) Risk Theory. Chapman and Hall, London.

Case, J., \& Gunstone, R. (2003) Going deeper than deep and surface approaches: A study of students' perceptions of time. Teaching in Higher Education,,8(1): 55-69.

Bank,C and Finlapson, W (2000).Successful Motivation of Students in Academic Activities. McClelland, D.C. Appleton-Century-Crafts.

Belfied, R (2000). Economic Principles for Education: Theory and Evidence. Cheltenham: Edward Elgar.

Broussard, S.C and Garrison, M.E( 2004) .The relationship between classroom motivations and Academic achievement in elementary school aged children. Family Consumer Science

Bowden, R. (1993)Trends and Effects of the Enrolment Legislation - A Comparative Study, Christchurch, New Zealand: Ministry of Education1993.

Dearing, R, (1994)The National Curriculum and its Assessment: A New Framework for Schools, London: School 
Curriculum and Assessment Authority.

Cetin, U., Jarrow, R., Protter, P., \& Yildirim, Y. Mathematics $>$ probability title: Modeling credit risk with partial information. Journal Reference: Annals of Applied Probability, 2994,14(3): 1167-1178.

Church, M. A., Elliot, A. J., \& Gable, S. L. (2001)Perceptions of classroom environment, achievement goals, and achievement outcomes. Journal of Educational Psycholog, 93(1): 43-54.

Fechner, S (2010) Effects of context-oriented learning on student interest and achievement 2010 in chemistry education. (vols. 95) Berlin: Logos Verlag.

Dalir, S, Shojaeian, Z and khodabandehloo, G (.2011). Survey on the motivation of nursing and Midwifery students toward their field of study selection- nursing and midwifery school 1387.Iranian Journal of Nursing Research.

Daniel, L,et al (1999). The Effects of Public School Choice on the Academic Achievement of Minority Students. Presented at the Annual Meeting of the American Educational Research Association (Montreal, Quebec).

Dessalegn Lemessa(1996). Study of Students Selection, Streaming and Training in Technical and Vocational Schools in Ethiopia. AAU.

Fortier,S,Vallerand,J(1995). Academic motivation and school performance: Toward a structural model. Contemporary Educational Psychology, 20, 257-274.15th Year No. 64 ADDIS ABABA 17th September, 2009

Freeman, R (2011). Supply and Salary Adjustments to the Changing Science Manpower Market: Physics, American Economic Review, vol. 65, 27-39.

Glenn, C.L., McLaughlin, K. and Salganik, L, (1993)Parent Information for School Choice: The Case of Massachussetts, Boston, MS: Centre on Families, Communities, Schools and Children's Learning, University of Boston.

Gordon, L,(1994a) Is school choice a sustainable policy for New Zealand? A review of recent research findings and a look to the future', paper, Christ-church, New Zealand: Education Policy Research Unit, University of Canterbury, New Zealand.1994a

Gordon, L. (1994b) 'Rich and poor schools in Aotearoa, New Zealand', New Zealand Journal of Educational Studies1994b, 29(2).

Hirschi, A., \& Läge, D. (2007). The relation of secondary student's career choice readiness to a six-phase model of career decision-making. Journal of Career Development, 34(2), 164-191.doi: $10.1177 / 0894845307307473$

Hirsch, D,(1995a)The other school choice-how should over-subscribed schools select their pupils?', open lecture, Institute of Education, London, May. (1995a)

Hirsch, D. (1995b) 'School choice and the search for an educational market', International Review of Education 1995b,41(3-4): 239-257.

Fogg, B.J,( 2003)Persuasive technology: using computers to change what we think and do, Morgan Kaufmann Publishers, Boston, 2003, 30-35.

Hirsh, H., Coen, M.H., Mozer, M.C., Hasha, R. and Flanagan, J.L,( 2002)“Room service, AI-style," IEEE intelligent systems, 14 (2). 8-19

OECD School, (1993)A Matter of Choice, Paris: Centre for Educational Research and Innovation (CERI), Organisation for Economic Co-operation and Development,

T. Eckes, (2000)The Developmental Social Psychology of Gender, Lawrence Erlbaum,[E-book] Available: netLibrary e-book.

University of Texas System Office of Academic Affairs Best Practices in Admissions for Undergraduate and Professional Programs July 2014.State of Illinois Admissions Review Commission Report \& $\begin{array}{llll}\text { Recommendations, } & \text { August } & 6009 .\end{array}$ http://www2.illinois.gov/gov/admissionsreview/Documents/FinalReport.pdf

Whitty, G., Edwards, T. and Gewirtz, S,(1993) Specialization and Choice in Urban Education, London: Routledge.

Willie, C.V. and Alves, M.J. (1993)A report on the implementation of the revised Boston "controlled choice" plan', unpublished consultants' report, Boston, MS.1993 